\title{
Medical Patents and the Right to Health - From Monopoly Control to Open Access Innovation and Provision of Medicines
}

Philippe Cullet and Hu Yuanquiong*

Forthcoming in 61 German Yearbook of International Law 2018 (2019).

ABSTRACT: The coming into force of the Agreement on Trade-Related Aspects of Intellectual Property Rights (TRIPS) in the mid-1990s led to a massive strengthening of intellectual property rights in the global South. This was particularly controversial concerning restrictions on access to medicines and set the stage for spirited debates concerning the impacts of medical patents on the realisation of the right to health in the context of the HIV/AIDS crisis. Efforts to reconcile the right to health and medical patents led to a minor amendment of the TRIPS Agreement that has hardly had any impact on the ground while further strengthening of patent protection was obtained, for instance, through bilateral agreements. In the human rights field, attempts to strengthen the protection afforded by the right to health have been partly diluted by efforts to strengthen the claims of inventors under human rights law. At this juncture, two main elements need to be taken forward. The first is to revisit our understanding of the human right to health to ensure, for instance, that there is no compromise in the liberal promise of universality, in particular access to medicines for every person who needs them. The second element is the need to rethink the way in which legal incentives are given to innovate. In a context where patents are the only recognised legal incentive to innovate in the medical field, this discourages the development of medicines for diseases that may affect mostly poor patients, since companies need to recoup their investments. Further, it militates against giving attention to other systems of medicine whose innovations can usually not be protected under the patent system, even where treatments are effective.

\footnotetext{
* Philippe Cullet (pcullet@soas.ac.uk) is Professor of international and environmental law at SOAS, University of London. Hu Yuanquiong (yuanqiong_hu@soas.ac.uk) is a researcher of law, a member of Law, Environment and Development Centre (LEDC) of SOAS, University of London, and a Teaching Fellow at Durham Law School, Durham University.
} 


\section{Introduction}

The relationship between medical patents and the right to health has been a fraught one over the past few decades. It was not always like that. Indeed, for many decades, even countries with significant pharmaceutical industries did not allow product patents over medicines, in recognition of the need to balance the advantages granted to the innovator and the need to foster the development of local capacity for producing medicines and support access to medicines for all. ${ }^{1}$ The situation progressively changed from the 1970s onwards in the global North and the adoption of the Agreement on Trade-related Intellectual Property Rights (TRIPS Agreement) made this a North-South issue. All developing country World Trade Organization (WTO) member States that had either had no medical patent protection or specifically rejected it were now bound to introduce the same. ${ }^{2}$ Only the least developed countries (LDC) that were always deemed sufficiently insignificant in economic terms were given a 10-year extension that has since been extended till 2033 with respect to pharmaceutical products. ${ }^{3}$ This sudden complete change of legal regime significantly curtailed countries' ability to frame intellectual property laws according to their needs, and limited the full freedom to manufacture and import generic medicines produced by other countries. ${ }^{4}$ Major producing countries for generic medicines, such as India, also had to amend their laws in order to meet their TRIPS Agreement obligations. ${ }^{5}$ This became an international political crisis in the late 1990s with the Acquired Immune Deficiency Syndrome (AIDS) epidemic that had started killing millions, particularly in the African continent. This was not because of an absence of suitable medicines but because most patients could not access them. This led to the only major compromise crafted within the WTO with the adoption of the Doha Health Declaration on the TRIPS Agreement and public

\footnotetext{
${ }^{1}$ See e.g. Graham Dutfield, Intellectual Property Rights and the Life Science Industries: Past, Present and Future (2nd ed., 2009), at 83.

2 Art. 65(2) Agreement on Trade-Related Aspects of Intellectual Property Rights (TRIPS Agreement) 1994, Marrakesh Agreement Establishing the World Trade Organization, Annex 1C, 1869 UNTS 299, providing for a five-year delay; for developing countries with restrictions on product patents, a ten-year transition period was provided under Art. 65(4).

${ }^{3}$ Art. 66(1) TRIPS Agreement and Decision of the Council for TRIPS of 6 November 2015, Extension of the Transition Period Under Article 66.1 of the TRIPS Agreement for Least Developed Country Members for Certain Obligations with Respect to Pharmaceutical Products, WTO Doc. IP/C/73, 6 November 2015.

${ }^{4}$ Carlos Correa, Intellectual Property Rights, the WTO and Developing Countries: The TRIPS Agreement and Policy Options (2000).

${ }^{5}$ Philippe Cullet, Intellectual Property Protection and Sustainable Development (2005).
} 
health in 2001, which took a few steps to foster better access to medicines without changing the basic architecture of the TRIPS Agreement. ${ }^{6}$ Yet, in the intervening 17 years, the Doha regime within the WTO framework has remained largely unused. ${ }^{7}$ In addition, the few countries that have tried to use existing flexibilities in the TRIPS Agreement, such as India have faced a backlash from multinational pharmaceutical companies. ${ }^{8}$

Attempts have been made for the past two decades to use the human right to health as a counternarrative that can be used not only to contest the scope of medical patenting from within the intellectual property rights regime but also from outside. This is an extremely powerful narrative that has the potential to derail the patent bandwagon. This is in particular the case as long as human rights remain the rights of individual human beings and communities. At the national level, fundamental rights take priority over other rights and can therefore be claims that trump economic interests. At the international level, there is in principle no hierarchy between treaties, apart from exceptions, such as ius cogens. Human rights are generally not considered to be peremptory norms but if a hierarchy was recognised, human rights should be hierarchically superior to patents.

The potential of human rights has been partly challenged through the 'discovery' of Article 15(1) International Covenant on Economic, Social and Cultural Rights (ICESCR) ${ }^{10}$ that addresses rights related to knowledge and science. This provision was largely ignored from 1948 (when inserted in virtually the same terms in the Universal Declaration on Human

${ }^{6}$ World Trade Organization (WTO), Declaration on the TRIPS Agreement and Public Health, Ministerial Conference - Fourth Session, WT/MIN(01)/DEC/2, 20 November 2001 (Doha Health Declaration).

7 Duncan Matthews, 'WTO Decision on Implementation of Paragraph 6 of the Doha Declaration on the TRIPS Agreement and Public Health: A Solution to the Access to Essential Medicines Problem?', 7 Journal of International Economic Law (2004) 73; Ellen 't Hoen, Private Patents and Public Health: Changing Intellectual Property Rules for Access to Medicines (2016), at 40-46.

${ }^{8}$ E.g. Médecins Sans Frontières, US Puts Unwarranted Pressure on India for Taking Legal Steps to Increase Access to Affordable Medicines (2013), available at https://msfaccess.org/us-puts-unwarranted-pressure-india-takinglegal-steps-increase-access-affordable-medicines.

9 Philippe Cullet, 'Patents and Medicines: the Relationship between TRIPS and the Human Right to Health', 79 International Affairs (2003) 139.

${ }^{10}$ International Covenant on Economic, Social and Cultural Rights (ICESCR) 1966, 993 UNTS 3. 
Rights) ${ }^{11}$ until the adoption of the TRIPS Agreement. In the past two decades, it has become an additional element in the human rights versus patents debate. ${ }^{12}$ This has been helpful in clarifying the scope of Article 15(1) to an extent but has also contributed to making the distinction between intellectual property rights and human rights less clear. This is made more complex by the recognition of property as a human right, in particular where the right to property is extended to intellectual property as has been done in the European context. ${ }^{13}$ Where human rights are extended to legal entities beyond natural persons, ${ }^{14}$ the field is muddled, and human rights are at risk of losing their transformational potential.

At this juncture, two main elements need to be taken forward. The first is to revisit our understanding of the human right to health to ensure, for instance, that there is no compromise in the liberal promise of universality, in particular access to medicines for every person who needs them. The second element is the need to rethink the way in which legal incentives are given to innovate. In a context where patents are the only recognised legal incentive to innovate in the medical field, this discourages the development of medicines for diseases that may affect mostly poor patients, since companies need to recoup their investments. Further, it militates against giving attention to other systems of medicine whose innovations can usually not be protected under the patent system, even where treatments are effective.

This article starts by examining the existing legal frameworks governing access to medicines, focusing on the one hand on incentives for innovation given by the patents system and on the other hand on the human right to health. It also identifies the limited options for reconciling the distinct and potentially opposed frameworks that existed in the wake of the adoption of the TRIPS Agreement. The next section moves on to examine developments that have taken place

${ }^{11}$ Universal Declaration of Human Rights (UDHR) 1948, United Nations General Assembly Res. 217 A (III), 10 December 1948.

${ }^{12}$ On the drafting of the similar UDHR provision, see Aurora Plomer, 'The Human Rights Paradox: Rights of Access to Science and Intellectual Property Rights', 35 Human Rights Quarterly (2013) 143.

${ }^{13}$ E.g. Laurence R. Helfer, 'The New Innovation Frontier - Intellectual Property and the European Court of Human Rights' 49 Harvard International Law Journal (2008) 1.

${ }^{14}$ European Court of Human Rights (ECtHR), Grand Chamber, Anheuser-Busch Inc. v. Portugal, Appl. No. 73049/01, Judgment, 11 January 2007. In this judgment, the ECtHR considered the trademark dispute between two corporations as falling within the right to property under the Convention for the Protection of Human Rights and Fundamental Freedoms 1950, 213 UNTS 222. 
since the beginning of the century in the field of human rights and intellectual property to resolve conflicts identified and harmonise different regulatory frameworks. The fourth section then considers alternatives to the existing frameworks and proposals. It does so by proposing a different framework for considering duties of States and private sector actors in the realisation of the right to health, by proposing to move towards open access innovation and by integrating considerations of equity or differential treatment for the global South to foster provision of existing medicines in all places where they are needed.

\section{Legal Frameworks to Ensure the Development, Manufacture and Access to Medicines}

The legal framework concerning access to medicines is made up of different elements. The first concerns the incentives given to human or corporate inventors to develop new medicines. At present, the main legal incentive is patents that provide a financially suitable incentive for the chemical-based pharmaceutical industry. Another dimension of the legal framework concerns the regulatory approval processes that need to be obtained before marketing a medicine protected under patent law. Regulatory approval is also applicable for generic medicines that are produced on an off-patent condition. There is no conditional link between the two insofar as the regulatory approval does not interfere with the research that can be directed in any field of medicine. The third concerns rules that focus on ways to ensure universal and equal access to medicines. The limited flexibility that exists in intellectual property frameworks, such as compulsory licensing is part of this set of measures even though these are framed as exceptions to the monopoly rights regime of patent law and not as rights of patients. The main rights-based framework is the human right to health that is structured around a completely different, and possibly opposed, philosophy that starts from the rights of patients to healthcare, including access to medicines, as a matter of a fundamental right and not as consumers of a patented good.

\section{A. Patents and Regulatory Framework Governing Medicines}

The TRIPS Agreement entered into force in 1995 under the auspices of the WTO. It is backed by a strong enforcement mechanism that contributed to shifting the forum of international 
governance of intellectual property from the World Intellectual Property Organization (WIPO) to the WTO. ${ }^{15}$

There are a number of key features of the TRIPS Agreement that have had significant impact in the field of medicines. Firstly, the TRIPS Agreement requires making patents available for all types of technologies. ${ }^{16}$ There is no distinction among technologies, even if they are related to medicines and food that may have strong humanitarian, public policy, and human rights implications. The TRIPS Agreement effectively ended countries’ option to exclude patenting on medical products.

Secondly, the TRIPS Agreement require patents to be granted upon the fulfilment of the criteria of novelty, inventiveness, and industrial applicability. ${ }^{17}$ It neither specifies the meaning of each of the criteria, nor distinguishes the criteria according to different technological fields. WTO members, therefore, have the right to determine and interpret the specificities of each of the criteria for each field of technology.

In practice, applying for multiple patents related to different aspects of the same medicine is a common strategy used by pharmaceutical companies, known as 'patent evergreening'. 18 Accordingly, if a country adopts a more relaxed approach to the interpretation of inventiveness, this may open up opportunities for companies to apply for patent on trivial changes of an old medicine. This can effectively secure longer monopoly position of a company even after the primary patent has expired. To the contrary, if a country adopts a stricter approach to interpretation, the same tactic of seeking patent on trivial changes of old medicines may be prevented. For instance, the patent examination guidelines of Argentina explicitly consider the

${ }^{15}$ Christophe May, 'Learning to Love Patents: Capacity Building, Intellectual Property and the (Re)production of Governance Norms in the "Developing World"', in Edmund Amann (ed.), Regulating Development: Evidence from Africa and Latin America (2006) 65.

${ }^{16}$ Art. 27 TRIPS Agreement.

17 Ibid.

${ }^{18}$ Amy Kapczynski, Chan Park, and Bhaven Sampat, 'Polymorphs and Prodrugs and Salts (Oh My!): An Empirical Analysis of "Secondary" Pharmaceutical Patents', 7(12) PLOS ONE (2012) 1; Gaurav Dwivedi, Sharanabasava Hallihosur, and Latha Rangan, 'Evergreening: A deceptive device in patent rights', 32(4) Technology in Society (2010) 324. 
patent claims concerning derivatives, such as combination of two compounds, or salt form of a known chemical compound, as lacking inventiveness and therefore do not merit protection. ${ }^{19}$

Although there is no formal adjudication on the compliance of diverse national approaches to patentability under WTO law, other forums have been used by patent holding pharmaceutical companies. For instance, after failing to secure patent protection on two derivative patents of two old medicines in Canada due to lack of merit under Canadian patent law, pharmaceutical company Eli Lily brought an Investor-States Dispute Settlement procedure against Canada by claiming investor protection. ${ }^{20}$

\section{TRIPS Flexibilities and TRIPS-Plus}

Although the TRIPS Agreement has harmonised the minimum standards of protection on pharmaceutical patents, there are still areas where national law and policies can retain full authority. In the context of access to medicines, the key flexibilities enshrined under the TRIPS Agreement include the freedom for members to determine the specific meaning of patentability criteria; the freedom for members to determine the grounds and procedures for issuing compulsory licences; the adoption of the doctrine of exhaustion to facilitate trade in goods under intellectual property protection; the adoption of exceptions of the patentable subject matter and the limitation on the right; and the use of competition law to tackle abuse of intellectual property rights. $^{21}$

Flexibilities allowed under the TRIPS Agreement have been used by various countries to balance public health needs and patent protection. ${ }^{22}$ However, the TRIPS Agreement provides a framework of minimum obligations but no ceiling. This opens the possibility to set out

\footnotetext{
${ }^{19}$ International Association for the Protection of Intellectual Property, Argentina - New Guidelines for examining chemical-pharmaceutical patent applications, July 2012, available at https://www.aippi.org/enews/2012/edition25/Ignacio.html.

${ }^{20}$ Brook Baker and Katrina Geddes, Corporate Power Unbound: Investor-State Arbitration of IP Monopolies on Medicines - Eli Lilly v. Canada and the Trans-Pacific Partnership Agreement, 29 September 2015, Northeastern University School of Law Research Paper No. 242-2015, available at https://ssrn.com/abstract=2667062.

${ }^{21}$ Ellen F.M. 't Hoen et al., 'Medicine Procurement and the Use of Flexibilities in the Agreements on Trade-related Aspects of Intellectual Property Rights: 2001-2016', 96 Bulletin of World Health Organization (2018) 185, available at http://www.who.int/bulletin/volumes/96/3/17-199364.pdf.

22 Ibid.
} 
standards of protection that are beyond the minimum obligations, so-called TRIPS-plus provisions. Legally speaking, adopting provisions in national laws that contain higher or stricter standards of protection is permissible as long as the provisions are not discriminatory or against other principles of the TRIPS Agreement. Yet, the reasons for adopting such provisions, and the impact of some of these provisions on access to medicines remain sites of controversy.

TRIPS-plus provisions are often endorsed in bilateral or regional free trade and investment agreements. ${ }^{23}$ In the context of pharmaceutical patents, the typical TRIPS-plus provisions focus primarily on two aspects. On the one hand, the provisions pursue longer periods of protection beyond the 20-year patent term. On the other hand, the provisions seek less stringent regulatory control on the types of patents that can be granted on the same medical product, as well as the manner of exploitation of the granted patents. The implementation and introduction of those provisions has been linked to a surge in prices of essential medicines in developing countries and hinders generic competition. ${ }^{24}$

\section{Exclusivity Derived From Regulatory Laws on Medicines}

Besides TRIPS-plus provisions that are directly affecting the administration of patents, longer exclusivity beyond the term of the patent can also be generated through other types of provisions.

One type of exclusivity concerns patent term extensions. The central claim for longer protection beyond the 20-year patent term is that the effective protection time may be shortened to less than 20 years ${ }^{25}$ for pharmaceutical companies due to the delay in completing clinical

${ }^{23}$ Susan K. Sell, 'TRIPS-Plus Free Trade Agreements and Access to Medicines', 28(1) Liverpool Law Review (2007) 41.

${ }^{24}$ Carlos M. Correa, Intellectual Property in the Trans-Pacific Partnership: Increasing the Barriers for the Access to Affordable Medicines (2017), South Centre Research Paper 62R, available at https://www.southcentre.int/wpcontent/uploads/2017/07/RP62R_IP-in-TPP-Increasing-the-Barriers-for-the-Access-to-Affordable-

Medicines_rev_EN.pdf.

${ }^{25}$ See for instance the European Commission, Study on the economic impact of supplementary protection certificates, pharmaceutical incentives and rewards in Europe (2018), available at https://www.copenhageneconomics.com/dyn/resources/Publication/publicationPDF/5/445/1527517171/cop enhagen-economics-2018-study-on-the-economic-impact-of-spcs-pharmaceutical-incentives-and-rewards-ineurope.pdf. 
trials and waiting for regulatory approval. ${ }^{26}$ Prolonging the term of exclusivity is pursued through either a direct extension of patent terms by the intellectual property office, such as those under the United States (US) Hatch-Waxman Act in $1984 ;^{27}$ or special protection to grant additional years of exclusivity rights based on the time frame for the regulatory approval of a medicine, such as the supplementary protection certificate in the European Union. ${ }^{28}$

Another type of exclusivity linked with regulatory laws concerns the protection of test data in the process of regulatory approval on medicines, which is often referred to as 'data exclusivity'. The trigger of this type of exclusivity can be traced back to the controversy concerning the exact meaning of Article 39.3 TRIPS Agreement. ${ }^{29}$ On the one hand, pro-industry interpretation considers that the clause creates a positive obligation for WTO members to provide exclusive rights to the holder of the undisclosed data when used in the market approval process. $^{30}$ On the other hand, research reviewing the negotiation history of this clause has revealed that due to the lack of consensus, the agreed final text entails the prime objective of protecting the undisclosed data against unfair competition. ${ }^{31}$ More importantly, it does not create an obligation for the public regulatory body to refrain from reviewing the market approval documents submitted by entities other than the first producer. ${ }^{32}$ Being one of the most controversial clauses under the TRIPS Agreement, Article 39.3 has unfortunately not been

${ }^{26}$ This line of argument has been used since the first patent term restoration mechanism was introduced in the United States (US). The US Food and Drug Administration introduced from 1962 the requirement and procedure to ensure the efficacy, safety and quality of medicines. E.g.: Alan D. Lourie, 'Patent Term Restoration: History, Summary, and Appraisal', 40 Food, Drug, Cosmetic Law Journal (1985) 351.

${ }^{27}$ Drug Price Competition and Patent Term Restoration Act, 35 U.S.C. $\$ 156$ (1984).

${ }^{28}$ European Parliament and Council Regulation 469/2009 of 6 May 2009, OJ 2009 L 152/1 (concerning the supplementary protection certificate for medicinal products).

${ }^{29}$ Art. 39.3 TRIPS Agreement.

${ }^{30} \mathrm{G}$. Lee Skillington and Eric M Solovy, 'The Protection of Test and Other Data Required by Article 39.3 of the TRIPS Agreement', 24(1) Northwestern Journal of International Law \& Business (2003) 1.

${ }^{31}$ Carlos Maria Correa, 'Unfair Competition and Under the TRIPS Agreement: Protection of Data Submitted for the Registration of Pharmaceuticals', 3 Chicago Journal of International Law (2002) 69; Carlos Maria Correa, Protection of Data Submitted for the Registration of Pharmaceuticals: Implementing the Standards of TRIPS Agreement (2002), South Centre Research available at http://www.who.int/medicines/areas/policy/protection_of_data.pdf.

32 Ibid. 
officially interpreted by the WTO. The ambiguity concerning its authoritative meaning leaves a critical gap in the WTO law in terms of balancing private interests with public health.

\section{B. Human Right to Health and Access to Medicines}

The right to health as a human right has been included in a number of international instruments but, like other economic and social rights, remains subject to criticism for being vague in content and intersecting with too many other rights. ${ }^{33}$ The ICESCR recognises everyone's right to the "enjoyment of the highest attainable standard of physical and mental health”. ${ }^{34}$ In the context of the ICESCR, General Comment 14 adopted by the UN Committee on Economic, Social and Cultural Rights (ICESCR Committee) admonishes that States are to refrain from interfering directly or indirectly with the enjoyment of the right, should take measures to prevent third parties from interfering with the guarantees provided and should adopt appropriate legislative, administrative, and other measures towards the full realisation of the right. $^{35}$

The ICESCR generally requires member States to take steps to the maximum of their available resources to progressively achieve the full realisation of the protected rights. It also indicates that these measures should be taken by each State separately as well as through international assistance and cooperation. ${ }^{36}$ The ICESCR thus recognises that the full realisation of the rights may require more than domestic measures. It is symptomatic that the ICESCR Committee has indicated in its authoritative interpretation of the right to health that States should facilitate access to essential health facilities, goods, and services in other countries and to provide the necessary aid when required. ${ }^{37}$ Further, States are to ensure that other international agreements they accede to do not adversely impact the right to health. These are indications that States must, for instance, cooperate in making medicines available free or at affordable prices.

\footnotetext{
${ }^{33}$ Cf. David P. Fidler, International Law and Infectious Diseases (1999).

${ }^{34}$ Art. 12 ICESCR.

${ }^{35}$ See United Nations (UN) Committee on Economic, Social and Cultural Rights (CESCR), General Comment No.14, The Right to the Highest Attainable Standard of Health, UN Doc. E/C.12/2000/4, 11 August 2000.

${ }^{36}$ Art. 2(1) ICESCR.

${ }^{37}$ General Comment 14, supra note 35, at para. 39.
} 
As expounded by the ICESCR Committee, the core obligations of the right to health include the necessity to ensure the right of access to health facilities, especially for vulnerable or marginalised groups. ${ }^{38}$ In the case of primary health care, this includes the promotion of a safe and adequate food supply and proper nutrition, an adequate supply of safe water and basic sanitation, immunisation against major infectious diseases, appropriate treatment of common diseases and injuries, and provision of essential medicines. ${ }^{39}$ In the case of Human Immunodeficiency Virus (HIV)/AIDS more specific elaborations of these obligations were given at the height of the crisis. The World Health Assembly called on its member States to increase access to treatment and prophylaxis of HIV-related illnesses through measures such as ensuring provision and affordability of medicines. ${ }^{40}$ The United Nations (UN) Human Rights Commission went in the same direction with its resolution on HIV/AIDS stating that access to medication in this context is one fundamental element for achieving the full realisation of the right to the enjoyment of the highest attainable standard of physical and mental health. ${ }^{41}$

Apart from emphasising the importance of accessibility and affordability, the ICESCR Committee has also indicated some circumstances in which the right to health is said to be violated. This includes, for instance, the repeal of legislation which is necessary for the continued enjoyment of the right to health, or the adoption of legislation or policies manifestly incompatible with pre-existing domestic or international legal obligations in relation to the right to health. ${ }^{42}$ Similarly there is a violation of the obligation to respect the right to health if a State fails to take into account its legal obligations when entering into bilateral or multilateral agreements. $^{43}$

\footnotetext{
${ }^{38}$ General Comment 14, supra note 35, at para. 12.

${ }^{39}$ See Art. VII Declaration of Alma-Ata, WHO International Conference on Primary Health Care, 12 September 1978, available at https://www.who.int/publications/almaata_declaration_en.pdf.

${ }^{40}$ World Health Assembly, HIV/AIDS: Confronting the Epidemic, WHO Doc. WHA53:14, 20 May 2000.

${ }^{41}$ Commission on Human Rights, Access to Medication in the Context of Pandemics such as HIV/AIDS, Commission on Human Rights resolution 2001/33, 23 April 2001, UN Doc. E/CN.4/RES/2001/33.

${ }^{42}$ General Comment 14, supra note 35, at para. 48.

${ }^{43}$ E.g. Statement by the CESCR on Human Rights and Intellectual Property, see CESCR, Report on the Twenty-Fifth, Twenty-Sixth and Twenty-Seventh Sessions, UN Doc. E/2002/22-E/C.12/2001/17, November 2001, Annex XIII, at para. 12 , specifically stating that 'any intellectual property regime that makes it more difficult for a State party
} 


\section{Limited Options for Reconciling the Different Options}

From the perspective of access to medicines, the two streams of law mentioned above have provided some, but limited, options for countries to take a holistic approach. There remain challenges when it comes to reconciling the two legal fields.

Firstly, human rights law and intellectual property law lack theoretical common grounds. ${ }^{44}$ Although the conflict between the two fields has been widely acknowledged and illustrated by UN human rights institutions, it remains difficult to find a viable theoretical standpoint from which the two approaches can be reconciled because they operate with different logic and ideological intent. ${ }^{45}$ The current human rights instruments also provide unclear guidance in this regard.

Secondly, although the UN human rights bodies have been explicitly discussing the impact of intellectual property law practices on the enjoyment of human rights, there is no explicit notion of human rights implications under WTO law nor laws administered by WIPO. On their part, the decisions of the WTO’s Dispute Settlement Body (DSB) have not provided clear guidance on the relationship between the two legal fields.

In addition, the effective implementation of public health-oriented TRIPS flexibilities has been instrumental to ensure access to medicines, but such efforts centre on the TRIPS Agreement without necessarily challenging the fundamental legitimacy of the system. The individual case approach may be effective in solving specific problems but may not help with establishing a long-lasting solution. For instance, one of the best outcomes of rigorous implementation of TRIPS flexibilities came under the ruling by the Supreme Court of India in Novartis v. Union of India. ${ }^{46}$ The case discusses Section 3(d) of the Indian Patents Act, which provides that derivatives from known medical substances do not merit patent protection unless significantly

to comply especially with its core obligations in relation to health, food, education or any other right set out in the Covenant, is inconsistent with the legally binding obligations of the State party'.

${ }^{44}$ Plomer, supra note 12.

45 Ibid.

${ }^{46}$ Supreme Court of India, Novartis AG v. Union of India \& Others, Judgment of 1 April 2013, (2013) 6 SCC 1. 
improved therapeutic efficacy is established. ${ }^{47}$ The Novartis judgment remains a landmark but recent research suggests that its precedent setting effect has not stopped the expansive patenting on secondary patent applications on known medicines in India. ${ }^{48}$ With a granting rate as high as $72 \%$ on secondary pharmaceutical patents in India, researchers have suggested that a more stringent bar on secondary patents as a whole is necessary in order to achieve the objective of tackling patent evergreening on pharmaceuticals. ${ }^{49}$

\section{Regulatory Developments Since the Beginning of the Century}

There have been various initiatives to take the debate forward from a patents and a human rights perspective since the beginning of the century. This has included attempts to further strengthen the intellectual property regime, for instance, through bilateral free trade agreements. There have also been initiatives trying to conceive of different incentives and ways to incentivise innovation outside of the patent system. In the human rights field, partly in reaction to the crisis over access to medicines, there have been several attempts to develop norms concerning the role, responsibilities, and duties of private sector actors in the realisation of human rights. This section examines some of the main initiatives in this context.

\section{A. From the TRIPS Agreement to the Doha Health Declaration and Beyond: Limited Attempts to Tame the Patent Regime}

In the context of finding a balance between intellectual property protection and access to medicines, three lines of normative issues are relevant, namely the implementation of the Doha Health Declaration, the reports adopted by the DSB, and issues related to the use of TRIPS flexibilities.

\footnotetext{
${ }^{47}$ Sec. 3(d) and Explanation of the Indian Patents Act, 1970 (as amended up to Patents (Amendment) Act, 2005).

${ }^{48}$ Feroz Ali, Sudarsan Rajagopal, Venkata S. Raman, and Roshan John, 'Pharmaceutical Patent Grants in India: How our Safeguards Against have Failed and Why the System Must be Reformed', Accessibsa (2018), available at https://www.accessibsa.org/media/2018/04/Pharmaceutical-Patent-Grants-in-India.pdf.

${ }^{49}$ Ibid., at 38.
} 
Firstly, the adoption of the Doha Health Declaration by the WTO Ministerial Conference in Doha in 2001 has been considered a 'turning point in political and legal relations at WTO'. 50 Especially important in the Doha Health Declaration is the affirmation of the freedom for WTO members to determine the grounds for issuing compulsory licenses and to take measures to ensure access to medicines for all. ${ }^{51}$

The Doha Health Declaration led to the adoption of an amendment to the TRIPS Agreement that entered into force in $2017 .^{52}$ The amendment grants a waiver under Article 31 TRIPS Agreement, allowing a country that lacks manufacturing capacity of the product to request another country to produce a specified patented product under a special compulsory license for exportation exclusively to the country in need. ${ }^{53}$ This mechanism has however remained essentially unused, apart from one single instance. ${ }^{54}$

Secondly, within WTO law the impacts and legitimacy of TRIPS-plus provisions have not been scrutinised carefully. In particular, there is neither authority nor mandate at the institutional level for the WTO to intervene in the substantive negotiation process and the resulting provisions of regional or bilateral trade or investment agreements. WTO members are only encouraged to register concluded trade agreements. ${ }^{55}$ There is in particular no obligation to stick to the minimum standards set forth in the TRIPS Agreement.

Another possible place where TRIPS-plus provisions might be reviewed more substantially in WTO is the DSB. However, it may be used both as a mechanism to review TRIPS-plus provisions and to nullify provisions of TRIPS flexibilities. For instance, in EU-Canada

\footnotetext{
${ }^{50}$ Doha Health Declaration, supra note 6. Frederick M Abbott, 'The Doha Declaration on the TRIPS Agreement and Public Health: Lighting a Dark Corner at the WTO', 5 International Journal of Economic Law (2002) 469; Ellen t' Hoen, 'TRIPS, Pharmaceutical Patents and Access to Essential Medicines: A Long Way from Seattle to Doha', 3 Chicago Journal of International Law (2002) 27.
}

${ }^{51}$ Doha Health Declaration, supra note 6, at para. 4.

${ }^{52}$ WTO General Council, Amendment of the TRIPS Agreement (Article 31.bis), WT/L/641, 6 December 2005.

53 Ibid.

54 The mechanism has only been used once between Canada and Rwanda.

55 The preferential trade agreements are registered under the WTO Preferential Trade Arrangements Database, available at http://ptadb.wto.org/, and the regional trade agreements are registered under WTO Regional Trade Agreements Database, available at rtais.wto.org. 
pharmaceutical patents, ${ }^{56}$ the provision allowing stock-piling of generic medicines shortly before the expiry of a patent has been ruled out by the DSB. This mechanism could have facilitated quicker access and foster competition. In US-Brazil patent protection, ${ }^{57}$ the complaint by the US over the local working requirement as one ground for issuing compulsory licence under the patent law of Brazil ended with a settlement agreement signed by both parties. Accordingly, Brazil committed to consult the US before issuing compulsory licenses on the ground of local working requirement in the future. ${ }^{58}$ This significantly reduced the level of flexibilities Brazil enjoys under the TRIPS Agreement, though the concerned provision of Brazil's patent law was untouched. In India, Brazil-EU seizure of generic drugs in transit, the complaint brought up by India and Brazil and joined by other members over the seizure of generic medicines in transit has triggered a consultation process started in 2010 that is still ongoing. The DSB has not yet ruled in this case and a clear jurisprudence over the issue of generic medicines in transit remains absent. In summary, the DSB has not provided a clear interpretation or guidance on a number of issues related to TRIPS flexibilities and TRIPS-plus. The DSB also makes no explicit reference to the human rights law framework in its interpretation of WTO law. The role of the DSB in reconciling the discrepancy between the two legal areas is therefore not promising.

Thirdly, with notable limitation, TRIPS flexibilities, especially compulsory licenses, continue to play an important role in facilitating access to medicines. Research has observed that between 2001 and 2014, governments have been authorising the use of patented products or processes without the consent of the patent holders in different forms based on various national laws and regulations. ${ }^{60}$ Compulsory licences have been used also in high income countries. ${ }^{61}$ One recent example of using compulsory license on medicine is in Germany concerning

\footnotetext{
${ }^{56}$ WTO, EU-Canada pharmaceutical patents, WT/DS114, 2000.

${ }^{57}$ WTO, US-Brazil patent protection, WT/DS199, 2001.

58 WTO, Brazil - Measures Affecting Patent Protection, Notification of Mutually Agreed Solution, WT/DS199/4 G/L/454 IP/D/23/Add.1, 19 July 2001.

${ }^{59}$ WTO, India, Brazil - EU seizure of generic drugs in transit, WT/DS408, WT/DS409, 2010.

${ }^{60} t^{\prime}$ Hoen, supra note 7.

61 Ibid.
} 
raltegravir, a medicine treating HIV/AIDS. ${ }^{62}$ The compulsory license was requested by the pharmaceutical company Merck Sharp Dohme (Merck) upon a legal battle with its competitor Shionogi, after they failed to conclude a negotiation on licensing related to a patent held by Shionogi that would affect Merck’s generic version of raltegravir which had already been put on the market in Germany. ${ }^{63}$ Even though the trigger of this particular compulsory license was commercially driven, the ruling by the German Federal Court of Justice upholding this compulsory license noted clearly the public health consequences of removing the generic version of raltegravir from the market. ${ }^{64}$

\section{B. Steps to Foster the Realisation of the Right to Health}

International human rights law has attempted to keep pace with developments in other fields of law, in particular with the game-changing reforms of international trade law. This has included the adoption of general comments to give more structured content to rights that were particularly at risk of being undermined by developments in other areas of law, such as the right to health, ${ }^{65}$ and debates around new areas, such as the role and responsibilities of corporations in the realisation of human rights.

With regard to the right to health, one of the steps taken by the ICESCR Committee was to make it clear that among core obligations related to the right to health is the provision of essential medicines. ${ }^{66}$ This is an important statement insofar as it makes it clear that there is a duty to provide and that the realisation of the right cannot be dissociated from access to medicines. This constitutes an important step in confirming the role of medicines in the broader context of the right to health but is also insufficient insofar as essential medicines do not cover all necessary drugs to tackle all diseases affecting a significant percentage of the population in the global South.

\footnotetext{
${ }^{62}$ Federal Court of Justice (Bundesgerichtshof), X ZB 2/17 of 11 July 2017.

63 Ibid.

${ }^{64} \mathrm{Ibid}$. See also. EPLAW Patent Blog, 'The First German Compulsory License Ever: Start of a New Era?', 17 October 2017, available at http://eplaw.org/de-the-first-german-compulsory-patent-license-ever-start-of-a-new-era/.

${ }^{65}$ General Comment 14, supra note 35.

${ }^{66} \mathrm{Ibid}$. , at para. 43.
} 
One of the central issues concerning medical patents is that they significantly impact the price of medicines. As a result, affordability is one of the issues that requires particular attention. In this context, General Comment 14 follows the line of general comments adopted in the 2000s that see affordability as a core dimension of different human rights. ${ }^{67}$ The only qualifications brought to this are that poorer households should not be 'disproportionately burdened' compared to richer households. ${ }^{68}$ The problem is that in many countries, people bear their own health expenses and may thus not be able to afford medicines, or only at the expense of forsaking other unavoidable expenses, for instance, on food or drinking water. In this context, the availability of generic drugs whose supply worldwide was much restricted after the coming into force of the TRIPS Agreement is central. Where generics are not available or where even generics are too expensive, patients rely on so-called traditional medicines. This is positive to the extent that this confirms that there is more than one system of medicine that patients can rely on. At the same time, this cannot lead to the conclusion that the poor may rely on cheaper plant-based medicines and the rich on more expensive allopathic medicines. This confirms that the issue in the debate on patents and the right to health is not just one of affordability. Indeed, governments also have to take positive measures to ensure provision of medicines in general, beyond essential drugs.

Other initiatives that have been taken since the beginning of the century centre around the place, role, and responsibilities of pharmaceutical industry. In the context of the backlash generated in particular by the campaign for access to HIV/AIDS drugs in the global South, companies started focusing on measures they could take to forestall the introduction of binding regulation. Significant attention was thus given to corporate social responsibility in the field of health, with companies adopting internal guidelines on the topic, such as in the case of Novartis. $^{69}$

In terms of international law-making, different attempts have been made to strengthen the framework for linking the right to health and the activities of pharmaceutical companies. On

\footnotetext{
67 Ibid., at para. 12(b).

68 Ibid.

69 Novartis, Corporate Responsibility Guideline - Novartis Global Guideline, June 2017, available at https://www.novartis.com/sites/www.novartis.com/files/cr-guideline-2017.pdf, at para. 2, mentioning that '[w]e respect human rights in all of our global operations'.
} 
the one hand, specific efforts have been made to bring human rights to bear on the activities of multinational companies. This has already included three different initiatives, starting with a set of norms on the responsibilities of transnational corporations and other business enterprises with regard to human rights. ${ }^{70}$ These were found to be too onerous for transnational corporations and were quickly side-lined in favour of a second process leading to the adoption of the 'Protect, Respect and Remedy Framework' (Ruggie Framework). ${ }^{71}$ This provides a limited first step in recognising that human rights cannot anymore be conceived only in terms of a relationship between individuals and the State. The need for further thinking and action in this field has been understood. On the one hand, the Human Rights Council agreed in 2014 to draft a binding legal instrument on the issue whose zero draft was put out in $2018 .^{72}$ On the other hand, the ICESCR Committee has adopted a general comment on the subject that recognises in very general terms that ' $[\mathrm{t}]$ he increased role and impact of private actors in traditionally public sectors, such as the health or education sector, pose new challenges’. More specifically, it calls on States to 'ensure that intellectual property rights do not lead to denial or restriction of everyone's access to essential medicines necessary for the enjoyment of the right to health'. ${ }^{74}$ This goes much further than an earlier initiative of the UN Special Rapporteur on the Human Right to Health whose guidelines for pharmaceutical companies did not go beyond enjoining companies to adopt a human rights policy statement, to respect the

70 UN Sub-Commission on Human Rights, Norms on the Responsibilities of Transnational Corporations and other Business Enterprises with Regard to Human Rights, UN Doc. E/CN.4/Sub.2/2003/12/Rev.2, 26 August 2003.

${ }^{71}$ UN Human Rights Council, Report of the Special Representative, Guiding Principles on Business and Human Rights: Implementing the United Nations "Protect, Respect and Remedy" Framework, UN Doc. A/HRC/17/31, 21 March 2011.

72 UN Human Rights Council, Elaboration of an International Legally Binding Instrument on Transnational Corporations and other Business Enterprises with Respect to Human Rights, UN Doc. A/HRC/RES/26/9, 14 July 2014, and Fourth session of the open-ended intergovernmental working group on transnational corporations and other business enterprises with respect to human rights, Zero Draft - Legally Binding Instrument to Regulate, in International Human Rights Law, the Activities of Transnational Corporations and Other Business Enterprises, July 2018, available at https://www.ohchr.org/Documents/HRBodies/HRCouncil/WGTransCorp/Session3/DraftLBI.pdf.

${ }^{73}$ CESCR, General Comment No. 24 (2017) on State obligations under the International Covenant on Economic, Social and Cultural Rights in the context of business activities, UN Doc. E/C.12/GC/24, 10 August 2017, at para. 21.

${ }^{74}$ Ibid., para. 24. 
rights of countries to use TRIPS flexibility, and to refrain from lobbying LDCs to enforce medical patents. $^{75}$

\section{Authors' Rights, Right to Benefit from Science and the Right to Health: New Battlegrounds in Human Rights}

Over the past two decades, a series of distinct debates have taken place around the place of intellectual property rights in human rights, the human right to benefit from scientific progress and culture, the potential human rights of intellectual property rights holders and specifically the impacts of medical patents on access to medicines in the broader context of the right to health.

Article 15(1) ICESCR recognises a series of rights related to contributions to human knowledge. The second right emphasises everyone's right to enjoy the benefits of scientific progress and, most importantly, its applications. ${ }^{76}$ This is crucial in a context where the applications of scientific innovation end up being increasingly protected by patent rights. This part of Article 15(1) seems to strengthen the perspective arising from the right to health in terms of providing guarantees to rights holders that they have an entitlement to access the products of human innovation that contribute to realise their rights, in this case particularly the right to health.

Article 15(1) also includes a third paragraph not found in the first draft of the ICESCR, ${ }^{77}$ which recognises the right of the 'author' to the protection of moral and material interests resulting from any scientific, literary, or artistic production. On the surface, this does not seem to have any relationship with (medical) patents since a patent holder is not usually defined as an author. The drafting history confirms that the Latin American countries proposing this addition wanted to protect authors against improper action on the part of publishers. ${ }^{78}$ This narrow

75 Ibid., paras. 1, 26, 29.

${ }^{76}$ Art. 15(1)(b) ICESCR.

77 Commission on Human Rights, Draft Covenant on Economic, Social and Cultural Rights, Report of the 10th Session, Economic and Social Council, 18th Session, Supp. 7, UN Doc. E/2573 - E/CN.4/705, 16 April 1954.

78 UN General Assembly, Third Committee, Draft International Covenant on Human Rights, Report of the 3rd Committee, UN Doc. A/3764, 5 December 1957. 
understanding borne by the text adopted has been rejected in General Comment 17 that understands the scope of protection to include broadly scientific publications and innovations, including knowledge, innovations and practices of indigenous and local communities. ${ }^{79}$ General Comment 17 is helpful in confirming that a legal entity cannot be deemed to be an 'author'. ${ }^{80}$ However, this fails to take into account the fact that it is very difficult to separate the natural person from the legal entity in patent applications since the individual inventor hardly exists today. Indeed, most patents are owned by large businesses. ${ }^{81}$ General Comment 17 also confirms that the human right contained at Article 15(1)(c) is meant to maintain a link between authors and their creations to allow them to enjoy an adequate standard of living and is separate from intellectual property rights which primarily protect business interests and investments. ${ }^{82}$ Thus, General Comment 17 states that it 'is therefore important not to equate intellectual property rights with the human right recognized in article 15 , paragraph 1 (c)'. 83 Yet, it also indicates that the realisation of the rights protected at Article 15(1)(c) depend on the enjoyment of other rights among which the right to property is singled out. ${ }^{84}$ The distinction between human rights claims and property (material or intellectual) is thus less clear than it appears at first sight.

The broader problem is that the ICESCR Committee decided to read Article 15(1)(c) in isolation from the other two sub-paragraphs. This was made even worse in the meantime since another separate General Comment was adopted concerning cultural rights, ${ }^{85}$ but Article 15(1)(b) remains unaddressed. The framework therefore remains incomplete. General Comment 17 fails to provide the overall picture that a joint reading of sub-paragraphs b and c

${ }^{79}$ CESCR, General Comment No. 17, The Right of Everyone to Benefit From the Protection of the Moral and Material Interests Resulting From any Scientific, Literary or Artistic Production of Which He or She is the Author, UN Doc. E/C.12/GC/17, 12 January 2006, at para. 9.

${ }^{80}$ lbid., at para 7.

${ }^{81}$ E.g. Peter Drahos, Who Owns the Knowledge Economy? - Political Organising Behind TRIPS (2004).

${ }^{82}$ General Comment 17, supra note 79.

83 Ibid.

84 Ibid.

${ }^{85}$ CESCR, General Comment No. 21, Right of everyone to take part in cultural life (Art. 15(1)(a) ICESCR), UN Doc. E/C.12/GC/21, 21 December 2009. 
would offer. Sub-paragraph b imposes on governments to ensure that everyone has access to all technologies necessary for the realisation of human rights and this must be done on a nondiscrimination basis. In addition, ICESCR member States have extra-territorial duties to foster realisation in other countries. Given the skewed distribution of scientific progress and its applications, they must foster technology transfer, something that is at the heart of intellectual property rights debates since the TRIPS Agreement package deal was sold to developing countries on the basis that stronger protection would ensure more effective technology transfer by private firms.

The truncation of Article 15(1) by the ICESCR Committee has also meant that it has avoided addressing the inter-dependence of the different rights contained in the provision. Article 15(1) is concerned with the balance between individual and collective rights of all individuals to take part in culture and enjoy the fruits of scientific development and the rights of individuals and groups making specific contributions to the development of science or culture. In this sense, Article 15(1) focuses on society's interest in culture and the development of science while also providing for the recognition of the rights of specific individual or collective contributions to the development of science, arts, or culture. It is unfortunate that the ICESCR Committee has failed to address this aspect since the balance between individual and collective interests is something that is central from a human rights perspective.

The gaps left by the ICESCR Committee have left the field open for more extreme views. Thus, Article 15(1)(c) is sometimes read as referring to existing intellectual property rights. ${ }^{86}$ It is refreshing that this is found problematic even by supporters of this idea since this would, for instance, mean that a trademark may be accorded the same importance in human rights terms as a patent. ${ }^{87}$ Yet, this also shows that the debate has shifted in a direction where there is now a need to justify measures to foster the realisation of the right to health in view of the claims at

\footnotetext{
${ }^{86}$ E.g. Sam Ricketson, 'Intellectual Property and Human Rights', in Stephen Bottomley and David Kinley (eds.), Commercial Law and Human Rights (2002) 187; and Robert L. Ostergard, 'Intellectual Property: A Universal Human Right?', 21 Human Rights Quarterly (1999) 156. See also the statement by a member of the CESCR that Art. 15(1)(c) is 'clearly intended to protect the creators of objects such as patents and trademarks'. CESCR, Thirtythird Session, Summary Record of the 51st Meeting, UN Doc. E/C.12/2004/SR.51, 3 May 2004, at 10.

${ }^{87}$ Ostergard, supra note 86 , at 175 , argues that under the UDHR intellectual property is designated as a universal human right, acknowledges that this is problematic, for instance, because the registered trademark for a multinational corporation is accorded the same importance and protection as a patent for medicinal purposes.
} 
Article 15(1)(c), something that can lead to a more restricted understanding of the scope of the right.

\section{Shortcomings of Medical Innovation and Alternative Pathways}

In parallel to the debate on patent and access to medicines, the discussion on the need to look for alternative means to ensure public health-driven innovation, rather than profit-driven innovation has been carried out and can be reviewed from two lines of development. The first and primary line of development concerns a series of policy processes within the remit of the World Health Organization (WHO). Initiated with the Report on Public Health, Innovation and Intellectual Property in 2006, ${ }^{88}$ the discussion on alternative approach to medical innovation has been carried out through the formulation of the Global Strategy and Plan of Action on Public Health, Innovation and Intellectual Property, ${ }^{89}$ the Consultative Expert Working Group on Research and Development, ${ }^{90}$ and the recent Comprehensive Roadmap for Access to Medicines and Vaccines. ${ }^{91}$ Among the processes, the focus on alternative model has been on the different approach to financing. The only normative proposal in this context concerns the possibility of drafting an international convention on global health Research and Development (R\&D). ${ }^{92}$ The R\&D convention has not materialised, and it appears increasingly uncertain whether States are open to negotiating such an instrument.

The second line of development concerns the trend of invoking open innovation in the context of drug discovery and development. The concept of 'open innovation' was initially invoked by big companies referring to a type of business model that involves some sort of collaborative

88 WHO, Report on Public Health, Innovation and Intellectual Property (2006), available at https://www.who.int/intellectualproperty/documents/thereport/ENPublicHealthReport.pdf?ua=1.

${ }^{89}$ WHO, Global Strategy and Plan of Action on Public Health, Innovation and Intellectual Property (2008), available at http://www.who.int/phi/implementation/phi_globstat_action/en/.

90 WHO, Consultative Expert Working Group on R\&D: Financing and Coordination (2013-2016), available at http://www.who.int/phi/cewg/en/.

91 WHO, Roadmap for Access 2019-2023 (2018), available at http://www.who.int/medicines/access_use/Roadmap_for_access_zero_draft.pdf.

92 E.g. Germán Velásquez and Xavier Seuba, Rethinking Global Health: A Binding Convention for R\&D for Pharmaceutical Products (2011), South Centre Research Paper 42, available at https://www.southcentre.int/wpcontent/uploads/2013/04/RP42_Rethinking-global-health_EN.pdf. 
work between internal and external actors, in contrast to a single company. ${ }^{93}$ It has also been understood as a process where 'a wide network of developers participate in building on a shared technological base that it freely available to all, ${ }^{94}$ However, the frequent use of the term is unhelpful because it has been defined only vaguely. ${ }^{95}$ For instance, the WHO has adopted a broad approach to consider whether an initiative is open innovation when it loosely recognises practices involving some degrees of departure from patent in R\&D. ${ }^{96}$ The concept has also been used by the industry with a different meaning, referring to a collaborative model of R\&D in contrast to the single firm based model. ${ }^{97}$ There remains ambiguity on both sides and the objectives are conflicting. In particular, the use of the open innovation concept in the industryled context refers to more than one kind of collaborative management of intellectual assets among specifically defined members.

\section{Towards Prioritising Access and Innovation to Realise the Right to Health}

Measures taken in the wake of the adoption of the TRIPS Agreement and the HIV/AIDS crisis to foster better access to medicines have fallen woefully short of what is needed to ensure every patient is provided with the drugs they need. This section focuses on a few elements that can contribute to taking debates ahead of the current status quo where the predominance of patents seems unassailable in debates over access to medicines.

\section{A. Right to Health: Rethinking the Obligations of the Duty Holders}

From a right to health perspective, one of the central issues that needs to be tackled in novel ways is the types of obligations of the State as duty holder and the broadening of duty holders

\footnotetext{
${ }^{93}$ Henry William Chesbrough, Open Innovation: The New Imperative for Creating and Profiting from Technology (2003).

94 James Boyle, 'Open Source Innovation, Patent Injunction and the Public Interest', 11 Duke Law \& Technology Review (2012) 30, 31.

${ }^{95}$ WHO, Research and Development to Meet Health Needs in Developing Countries: Strengthening Global Financing and Coordination, Report of the Consultative Expert Working Group on Research and Development: Financing and Coordination (2012), available at https://www.who.int/phi/CEWG_Report_5_April_2012.pdf, at 30.

96 Ibid.

${ }^{97}$ Chesbrough, supra note 93 , at 828.
} 
to actors that have significant capacity to influence access to medicines. Some of the central issues that arise concern public funding of upstream $R \& D$ activities, which would foster the realisation of access to scientific progress as a human right.

\section{Duty of State to Fund Research, Manufacture, or Regulate Prices}

The right to health may be subject to progressive realisation but it also includes requirements for the State to adopt immediate measures within available resources and capacity. ${ }^{98}$ In the context of access to medicines, the previous proposal for the global health R\&D treaty indicates that there are possibilities of sharing resources among nations and making it mandatory for each State to contribute to a global financing pool for medical innovation. However, those discussions have not made an explicit connection with broader public health objectives. Further, the R\&D treaty has not been developed further into a concrete negotiation or draft.

According to earlier proposals, the $R \& D$ treaty should ensure equitable access to the innovation output and set clear duties for participating countries to collectively govern, and ensure the conduct of essential health R\&D at the global level. ${ }^{99}$ Especially, proposals have suggested that the objectives of the treaty should include allocating 'fairly the costs of supporting needs driven medical research and development, in particular, to meet the health needs of developing countries'. ${ }^{100}$ Accordingly, the duty of the state in funding the R\&D entails

[n]orms and mechanisms to ensure sufficient, regular, predictable and sustainable financing for R\&D for type I, II and III diseases. Such financing should be primarily from government contributions based on their level of development and managed by structures that are guided by the principles of transparency, inclusiveness that stress

\footnotetext{
${ }^{98}$ General Comment 14, supra note 35, and General Comment 17, supra note 79.

99 Think tanks and civil society organisations have made proposals concerning the content of the treaty. E.g. Velásquez and Seuba, supra note 92; Joint Submission by Health Action International, Knowledge Ecology International, Médecins Sans Frontières, Third World Network, An Essential Health and Biomedical R\&D Treaty, June 2011, available at http://www.who.int/phi/news/phi_1_joint_submission_en.pdf.

100 Ibid.
} 
participation of developing countries in decision-making processes, equity and high governance standards. ${ }^{101}$

The necessity of leveraging the regulatory authority of the WHO at the international level and governmental agencies at national levels, as suggested by the proposals, requires that the State not only commit to contribute financially to R\&D activities, but also need to make sure that the results from the $R \& D$ are affordable, including measures to ensure the price of the relevant products will not be determined by the cost of $R \& D$ as claimed by industrial drug

developers. ${ }^{102}$ Those proposals opted for a strong regulatory approach with the role of government put at the centre, in contrast to the market-determinist approach taken by the current patent centric model. However, the strong regulatory approach might in itself be a political hinderance for the further development of the global R\&D treaty proposal.

\section{Sharing Duties and the Private Sector: Rethinking Obligations of Duty Holders in International Law}

Debates concerning human rights and transnational corporations have been at best timid. The Ruggie Framework constitutes an acknowledgment that the existing system that pits individuals against States has outlived its utility, particularly in a South-North context where many small countries of the global South may be smaller economies than the companies that come to do business. Yet, it needs a much deeper engagement that does not limit itself to looking at corporations vis-à-vis individuals but that looks more broadly at the links between incentives for innovation, the type of innovation that is socially desirable and the kind of reward that the innovator can claim in a context where the end point - the realisation of the human right to health of individuals and communities - must remain the central aim. In other words, the duties of corporations must start upstream of current debates.

The starting point is to ensure that corporations innovate to ensure the realisation of the human right to health for rights holders, who may happen to be 'patients' but cannot be 'consumers' since they are right holders. Their obligations are thus linked to public health policies drawn by governments that seek to address the main diseases affecting significant proportions of the

\footnotetext{
101 lbid, at 4

102 Ibid.
} 
population, starting with life-threatening diseases and moving ahead from there, with lifestylerelated conditions that can be easily prevented through better preventive measures enshrined in public sector measures coming last.

In a context where health-related innovation is in large part, though not entirely, linked to levels of economic development, there is also an international dimension to the national public health policies adopted by individual governments. This is borne out of the ICESCR's admonishment that member States have duties that go beyond their own jurisdiction. This is particularly relevant for health where no LDC has the resources to develop new drugs to address all their main diseases, as was the case for countries severely affected by HIV/AIDS that needed to rely on medicines developed and often manufactured elsewhere. This framework for extraterritorial obligations also needs to be much strengthened so that it goes beyond academic debates into practical policy impacts that can make a difference for patients. This could start simply with a focus on technology transfer, one of the big unfulfilled promises whose need is undiminished and that is enshrined in dozens of treaties. In fact, technology transfer was one of the specific advantages that was advertised to developing countries during the TRIPS Agreement negotiations to convince them to sign up. The rationale was that stronger standards of intellectual property protection would ensure that the transfers that had not been forthcoming in previous decades would now flow to developing countries. The experience of the past couple of decades is that a few large and technologically already more advanced countries have probably benefitted from the new legal regime, but the bulk of small developing countries have not. Further, in an acknowledgment that intellectual property protection is not actually what drives technology transfer, LDCs have essentially been told that they do not need to implement their TRIPS Agreement obligations. This is clearly not supposed to imply that they will not benefit from technology transfers in the health sector.

\section{B. Redefining Openness in Medical Innovation to Ensure Access to Medicines for All}

The unsettled tension between human rights law and intellectual property regime discussed above and the remaining limitations in seeking to reconcile the different areas of law suggest the need to pursue a more systemic rethinking of the normative conditions for medical innovation. In contrast to the current monopoly and exclusivity-based model, a new definition of openness in ensuring access and innovation suggests at least three levels of reconfiguration. 
The first level concerns the openness of actors in the innovation practices, in contrast to the patent holder centric logic in the current normative order. This requires the re-identification and recognition of contributions and roles of non-patent holder entities, including the actual inventors of a given technology, clinicians who play important role as user innovators, academic researchers, and patients.

The second level of openness concerns the norms of knowledge production and dissemination in a collective and community-based context, rather than depending on individual entities. The innovators' community consists of multiple players in the process of making medical knowledge and innovation. This should be the collective entity determining the mechanism and norms upon which medical knowledge can be developed and shared openly with due scrutiny by peer users.

The third level of openness involves the flexible and plural normative mechanisms including the analogy to the open source model in the context of computer software development. As analysed by considerable literature, the open source movement demonstrates the possibility of a community-norm based model of innovation that do not rely on the individualistic proprietary regime. ${ }^{103}$ The rather flexible and voluntary participation is in fact stringently about by the commonly recognised norms in the community of innovators. Violating the community rules will not necessarily result in liability in legal terms but will lose access to the communal resources from which the continuation of innovation can be ensured.

Instead of loosely labelling any collaborative initiative as open innovation, the redefined openness entails a genuine possibility of departure of both the narrative and substance aspects of medical innovation from the current proprietary rights-based model. Narrative wise, it could help altering the almost default starting point of the debate, shifting from focusing on managing patent inside the system toward clarifying the community of innovators and the meaningfulness of medicines towards the users. In substance, it also helps moving the normative attention from

\footnotetext{
${ }^{103}$ There is rich literature discussing the open source model in computer software development, and the viable analogy to innovation in medical context. E.g. Steven Weber, The Success of Open Source (2004); Georg von Krogh and Eric von Hippel, 'Special Issues on Open Source Software Development', 32(7) Research Policy (2003) 1149; Georg von Krogh et al., 'Community, Joining, and Specialisation in Open Source Software Innovation: A Case Study', 32(7) Research Policy (2003) 1217; Janet Hope, Biobazaar: The Open Source Revolution and Biotechnology (2008), at 44.
} 
focusing on reforming the current patent law, toward engaging other normative institutions in order to realise the access to medicines for all as part of the right to health.

\section{Preferential Treatment: Ensuring Provision of Necessary Medicines in the Global South}

Access to medicines as a core dimension of the right to health is an international issue because many countries do not have the scientific, technological, or economic capacity to invest in research and development or large-scale manufacturing of medicines. Ensuring more effective technology transfers would be a way to ensure that more capacity is built in small developing countries and LDCs. This brings up the South-North context that has defined international relations for decades but is not always acknowledged sufficiently. In fact, in the WTO context, the starting point was to try and eliminate as much preferential for developing countries as possible and (re)start from the older paradigm that sees legal equality as the best basis for achieving equitable outcomes.

The reality of the world over the past couple of decades is that the majority of developing countries are not comparatively better off than they were in the early 1990s, with the exception of a few large countries whose economic growth gives the impression that the global South in general has been doing much better than earlier. In fact, the relative position of LDCs has, for instance, not improved even though they have in principle been the object of special attention in development policy by the very fact of being singled out as least developed. This points towards the need to strengthen existing preferential treatment guarantees, for at least all LDCs and countries with low human development scores on the Human Development Index. ${ }^{104}$

The need for strengthening preferential treatment is borne from two parallel points. Firstly, in the WTO context, the attempt to restrict preferential treatment has had devastating impacts on the lives of millions of people in the global South. This experiment must stop in a context where it is abundantly clear that the gap in human development between LDCs and Organisation for Economic Co-operation and Development-countries will remain vast for decades to come. There is thus no risk of these countries becoming too rich to warrant the preferential treatment they are given. The neoliberal policy context that has prevailed over the

\footnotetext{
104 Philippe Cullet, 'Differential Treatment in Environmental Law: Addressing Critiques and Conceptualizing the Next Steps', 5 Transnational Environmental Law (2016) 305.
} 
past couple of decades rejects such preferential treatment, as seen in the case of environmental agreements where attempts to water down differential treatment have been made repeatedly

and with some measure of success in the climate change context. ${ }^{105}$ Yet, equity demands more preferential/differential treatment, not less.

Secondly, as noted above human rights need to be conceived more clearly in an international context with extraterritorial obligations of the global North being given more importance. This implies that human rights are increasingly to be seen beyond the traditional individual/State relationship to add an international dimension. In the context of the right to health and access to medicines, this must be done from the start in view of existing inequalities among States. As a result, a more international understanding of human rights obligations must include differential treatment as one of its building blocks. This is necessary to ensure that the benefits of this broader understanding reach the people who need them both, starting with LDCs and all other countries with low human development.

\section{Conclusion}

Access to medicines has been recognised as a central component of the human right to health. This should help in giving priority to the right to health over other considerations, in particular economic ones. Yet, today's international regulatory framework is largely structured around incentives given to innovators in the form of patent rights. Their importance for the chemicalbased pharmaceutical industry and the concentration of the industry in the hands of a global oligopoly has ensured that policy-makers have shied away from taking any serious measures that would affect the economic interests of pharmaceutical companies. As a result, the TRIPS Agreement, which was resisted by many developing countries in the first place and got a bad name for itself before it was even implemented in the global South in the context of the HIV/AIDS crisis of the late 1990s, has only been revised in a minimalist fashion through an amendment that only came in force in 2017 and has not been used.

Debates within the human rights field have not necessarily brought about the conceptual clarity that is missing within WTO with regard to giving patients the priority they deserve in terms of access to medicines and in terms of rethinking systems of innovation for new medicines. In

105 Ibid., at 318. 
particular, while debates in human rights organs have addressed issues related to access to medicines, they have often failed to provide clear hierarchical priority to the rights of patients over companies and the parallel debate on authors' rights has made the situation even worse since it tends to put in parallel inventors' rights and patients' rights.

The international society of the twenty-first century needs to be able to give different and new answers to the challenges faced by millions of people without access to medicines and millions of people in need of new medicines. The current system wherein human rights are not recognised as being hierarchically superior to patent rights leads in practice to WTO norms prevailing in disputes where other norms are at best partially considered. This is morally problematic given, for instance, the direct links between the rights to life and health. There are various ways to address this conundrum. Some authors have proposed that it would be best to recognise that the 'two systems of law are like oil and water' and that the solution is to dissociate patent law from human rights. ${ }^{106}$ This outcome that lets patent rights prevail in practice over human rights concerns is something that we find unacceptable. This article therefore proposes new avenues to re-orient the debates around access to medicines to ensure that the right to health prevails over other concerns, to recognise that innovation based on sharing is a viable alternative to the current exclusionary model and to focus on the need to give much more importance to the inequalities between the majority of small developing countries and LDCs and countries with high human development, calling for much stronger differential measures to ensure medical innovation addresses the needs of these countries and to ensure existing medicines are provided to all patients needing them.

\footnotetext{
${ }^{106}$ Siva Thambisetty, Improving Access to Patented Medicines: Are Human Rights Getting in the Way? (2018), Law, Society, and Economy Working Papers 3/2018, available at http://eprints.Ise.ac.uk/87540/1/Thambisetty_Access\%20to\%20Patented\%20Medicines_Author.pdf, at 5.
} 